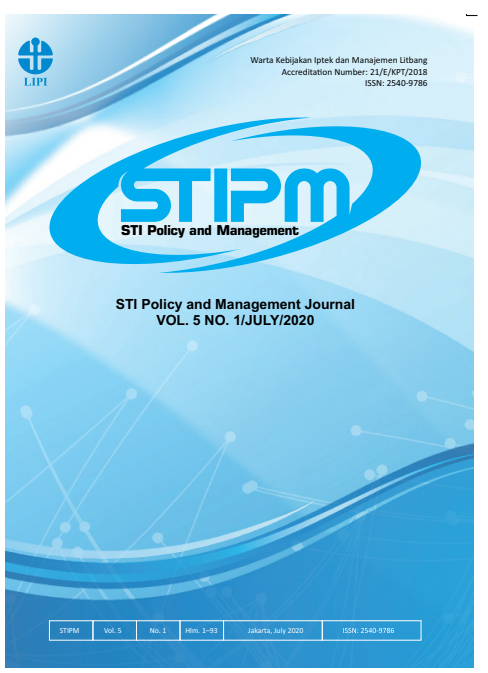

Journal of STI Policy and Management

Publication details, including instructions for authors and subscription information: http://www.stipmjournal.org/

\title{
Policy Role in Innovation Network: Case of Indonesian food processing firms
}

Erman Aminullah*, Wati Hermawati*, Trina Fizzanty*, and Nur Laili*

*Research Center for Science, Technology, Innovation Policy

and Management

Indonesian Institute of Sciences (LIPI)

Version of record first published: 15 July 2020

To cite this article: Aminullah, E., Hermawati, W., Fizzanty, T., and Laili, N. (2020). Policy role in innovation network: Case of Indonesian food processing firms. Journal of STI Policy and Management, 5(1), 33-50.

To link to this article: http://dx.doi.org/10.14203/STIPM.2020.190

ISSN 2540-9786 (Print); ISSN 2502-5996 (online)

Accreditation Number: 21/E/KPT/2018

Full terms and conditions of use: https://creativecommons.org/licenses/by-nc-sa/4.0/

You are free to:

- Share : copy and redistribute the material in any medium or format

- Adapt : remix, transform, and build upon the material

- The licensor cannot revoke these freedoms as long as you follow the license terms.

Under the following terms:

Attribution - You must give appropriate credit, provide a link to the license, and indicate if changes were made. You may do so in any reasonable manner, but not in any way that suggests the licensor endorses you or your use.

NonCommercial - You may not use the material for commercial purposes.

ShareAlike - If you remix, transform, or build upon the material, you must distribute your contributions under the same license as the original.

No additional restrictions - You may not apply legal terms or technological measures that legally restrict others from doing anything the license permits.

Notices:

- You do not have to comply with the license for elements of the material in the public domain or where your use is permitted by an applicable exception or limitation.

- No warranties are given. The license may not give you all of the permissions necessary for your intended use. For example, other rights such as publicity, privacy, or moral rights may limit how you use the material.

- If you copy the dataset merely to extract the uncopyrightable data elements would not need permission to do so. However, if you republish the full dataset or using the copyrightable data layers require a permission from Research Center for STIPM, Indonesian Institute of Sciences. 


\title{
JOURNAL OF SCIENCE, TECHNOLOGY AND INNOVATION POLICY AND MANAGEMENT (STIPM JOURNAL), Volume 05, Issue 01, July 2020
}

\author{
FOREWORD by EDITOR-in-CHIEF
}

We are very pleased to inform the readers that Journal of Science, Technology, \& Innovation Policy and Management (STIPM Journal) Vol. 5, No. 1, July, 2020 is now ready for public reading and views.

STIPM Journal is an online research journal managed by the Research Center for Science, Technology, Innovation Policy and Management, Indonesian Institute of Sciences (P2KMI-LIPI). This journal in fact provides scientific information needed mostly by the research scholars. As a peer reviewed journal, STIPM provides free access to research thoughts, innovation, and original discoveries.

In this edition, the STIPM Journal contains six articles dealing with science, technology and innovation policy and management written by scholars from Japan and Indonesia.

The first article, entitled Dynamics of Organisational Capability of Japanese Construction Firm towards Open and Service Innovation through PPP/PFI arrangement was written by Taeko Suehiro, Kumiko Miyazaki. This study examines the influence of Public-Private Partnership (PPP) — or, more specifically, Private Finance Initiative (PFI) - arrangements in relation to open and service innovation in construction firms in Japan.

Second article was composed by Pratiwi, entitled The Role of Local Community Associations as Intermediaries: A Multiple Case Study in a Rural Area. This study investigates the role, capabilities, and the outcome of the engagement of local community associations as intermediaries in different sectors such as agriculture, food processing, and tourism product. This study describes the way innovation promotes rural development.

Erman Aminullah et al., present the third article, Policy Role in Innovation Network: Case of Indonesian Food Processing Firms. The objective of the study is to reveal internal and external factors that affect the use of network relations for innovation, with a focus on mapping the policy role in innovation networks. The study was undertaken through case analysis in four different firms in Indonesia.

The fourth article entitled Potentials of Research Activities in Medicines at the Indonesian Institute of Sciences (LIPI) was by Hadi Kardoyo et al. This article reveals the findings of research priority setting (RPS) in the field of medicine and health at the Indonesian Institute of Sciences (LIPI) in 2017. The RPS stage had been conducted with the Delphi Method and produced five major issues.

Next article entitled What We Learn from Innovation Failure: A Review of Clean Water Postpaid Service in Remote Island Indonesia Using Sea Water Reverse Osmosis (SWRO) Technology was presented by Rendi Febrianda and Nur Laili. Final article was compiled by Syukri Yusuf Nasution and Yovita Isnasari with the title Valuation IP of Nano Technology to Make a Nano Tea Based on Mangosteen Peel as a New Product Development. This article analyses the potential of nano technology in developing new 
product, such as how much the potential of the turn over if the technology is used to produce a nano tea based on mangosteen peel, how much the royalty rate, and how is the positioning of the technology in in relation with legal aspects, technological readiness, market condition and finance.

In addition to all articles presented in this volume, we also would like to thank the authors, editors, and reviewers who have worked very hard in this edition. We hope that all articles featured in this edition are useful for the readers.

Jakarta, 16 July 2020

Editor-In-Chief 



\section{JOURNAL OF STI POLICY AND MANAGEMENT}

Volume 5, Number 1, July 2020

\section{LIST OF CONTENTS}

Dynamics of Organisational Capability of Japanese Construction Firm towards Open and Service Innovation through PPP/PFI arrangement

Taeko Suehiro and Kumiko Miyazaki.

The Role of Local Community Associations as Intermediaries: A Multiple Case Study in a Rural Area

Pratiwi

Policy Role in Innovation Network: Case of Indonesian food processing firms

Erman Aminullah, Wati Hermawati, Trina Fizzanty, and Nur Laili.

Potentials of Research Activities in Medicines at the Indonesian Institute of Sciences (LIPI)

Hadi Kardoyo, Mia Rahma Romadona, and Setyowiji Handoyo

What We Learn from Innovation Failure: A Review of Clean Water Postpaid Service in Remote Island Indonesia Using Sea Water Reverse Osmosis (SWRO) Technology

Rendi Febrianda and Nur Laili

Valuation IP of Nano Technology to Make a Nano Tea Based on Mangosteen Peel as a New Product Development

Syukri Yusuf Nasution and Yovita Isnasari 


\title{
if STI POLICY AND MANAGEMENT \\ LIPI Journal homepage: http://www.stipmjournal.org
}

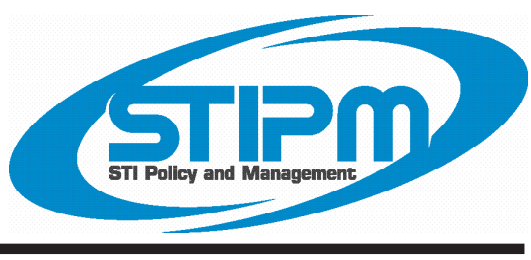

\section{Policy Role in Innovation Network: Case of Indonesian Food Processing Firms}

\author{
Erman Aminullah*, Wati Hermawati*, Trina Fizzanty*, and Nur Laili* \\ *Research Center for Science, Technology, Innovation Policy and Management \\ Indonesian Institute of Sciences
}

\begin{tabular}{|c|c|}
\hline ARTICLE INFO & ABSTRACT \\
\hline $\begin{array}{l}\text { Article History: } \\
\text { Received : 08 January } 2020 \\
\text { Revised : } 27 \text { May } 2020 \\
\text { Accepted : } 27 \text { May } 2020 \\
\text { Available online : } 15 \text { July } 2020\end{array}$ & $\begin{array}{l}\text { The objective of the study is to reveal internal and external factors } \\
\text { to firms that affect the use of network relations for innovation, } \\
\text { with focus on mapping the policy role in innovation networks. The } \\
\text { study was undertaken through case analysis in four different firms. } \\
\text { The study found that the number of actors in network relations }\end{array}$ \\
\hline $\begin{array}{l}\text { Authorship Contribution: } \\
\text { Authors contribution are equal. }\end{array}$ & $\begin{array}{l}\text { affects upgrading of a good or service value. The upgrading is } \\
\text { activated by learning events, which relate to organizational changes, } \\
\text { namely refocusing on the core business, restructuring the internal }\end{array}$ \\
\hline $\begin{array}{l}\text { Keywords: } \\
\text { Innovation network, } \\
\text { Policy role, } \\
\text { Organizational change, } \\
\text { Upgrading, } \\
\text { Sectoral system of innovation }\end{array}$ & $\begin{array}{l}\text { organization, undertaking management change, and applying } \\
\text { responsive management practices. The specific policy roles in } \\
\text { stimulating the network effect for innovation are 1) government } \\
\text { facilities for the ease of doing business by continuing to reduce } \\
\text { bureaucratic processes to regulate standard requirements, 2) } \\
\text { strengthening government agencies-industry relations by establishing } \\
\text { promotion of representatives of Indonesian food products overseas, } \\
\text { 3) government brokerage and matching services for global trading } \\
\text { by arranging trade fairs, business seminars, or supporting modern } \\
\text { information technologies, and 4) government relaxation on import } \\
\text { restriction to maintain a stable supply of raw materials for food } \\
\text { processing. The substantive contribution of this scientific study is } \\
\text { the provision of the concept of policy role in innovation networks } \\
\text { viewed from the sectoral system of innovation. }\end{array}$ \\
\hline
\end{tabular}

C2020 P2KMI-LIPI All rights reserved

\section{INTRODUCTION}

Innovation performance of a firm depends on both the firm's own innovation activities and other firms' innovation in the production network. The inter-dependence among firms within

\footnotetext{
* Corresponding Author.

E-mail: aminullahe@yahoo.com
}

a production network will enhance the level of innovative activities by all parties involved in the production network. Global value chain (GVC) studies recognize the concept of innovation with network effects that have a policy role for industrial upgrading in both developed and developing countries (Humphrey \& Schmitz, 2002). Such innovations with network effects require 
upgrading of the entire production network to improve innovation performance at firm level. Innovations with network effects will also bring change in transmission mechanisms of innovation policies and innovation policy framework.

In the food processing industry, the process of upgrading is subject to growth formation, which is determined by the quantity and quality of materials supplied that affect inter-firm interactions. Aminullah, Fizzanty, Sari, Rahmaida, \& Susanto (2017) mentioned that in the fishery processing industry, the marine resource policy will create a firm's growth formation by 1) facilitate firms' that interact with local universities or public research institutes; 2) encourage producer's firms to improve their competitiveness by shifting to higher added value fish products; 3 ) improve marine infrastructures for expanding fish production throughout the country, and 4) provide institutional support through various schemes of innovation and trade policies.

Moreover, adoption of information and communication technologies (ICTs) lead to changes in the way a firm organizes itself and builds relationships with other entities. In the agri-food industry, innovations, firm size, and competition are strongly related to the likelihood of adopting ICTs, where rural areas are faster in ICT adaptation as compared to urban areas (Martinez-Gomez, Domenech, \& Mas-Verdú, 2016). However, ICTs, especially through internet-based communication technology can play an important role in the creation of new discussions, collaborations, and alliances among stakeholders whose voices were previously not captured or at least not sufficiently amplified or taken into consideration. More specifically, ICTs contribute to the collective learning processes around the seasonality of food growing and consumption (Vallauri, 2014).

In the food and beverage industry, the nonresearch and development (R\&D) activities are crucial in understanding the process and product innovation. The role of customers as sources of innovation, performing technology assessment, testing of production, and training are decisive factors for outputs innovation. Furthermore, the role of networks, such as business partners and public research institutions, also play a crucial role in achieving successful innovations in the food industry. The companies' networks related to product innovation determine a product's market performance, where the partners that supplied ingredients and/or raw materials and machineries and/or equipment provided sources of ideas for new products (Enzing, 2009). The realization of advanced food technology invention is supported by appropriate network organizations that facilitate knowledge exchange and interaction with experts and researchers (Schiefer \& Deiters, 2016).

Based on innovation along the production networks in the food sector related to resource policy, ICT's role, and networks organizations, the objective of this study is to reveal internal and external factors to firms that affect the use of network relations for innovation, with a focus on mapping the policy role in innovation network. This research examines four aspects in realizing the objective: 1) firm's innovation and upgrading, including types of innovation, forms and drivers of upgrading, constraints of upgrading, and the role of lead firms in the production network; 2) learning events and networks, covering the roles of internal and external parties in innovating and upgrading, role of ICTs in innovating and upgrading, and positive and negative effects of networks; 3) learning mechanism in upgrading, comprising ways of knowledge and skill improvement, and paths of network expansion in logistic, production, and distribution; and 4) policy role by mapping policies and incentives to induce innovation network, R\&D collaborations, and inter-firm cooperation in the production networks.

The study was undertaken through case studies in four firms. The four firms categorize as big companies and were selected based on their global coverage activities including R\&D activities. Case 1: company A produces functional food (containing pharmaceutical ingredients). Case 2: company B produces food seasoning. Case 3 : company $\mathrm{C}$ produces healthy food products (for better life and health), and Case 4: company D produces frozen meat. Data and information for each case were collected by conducting in-depth interviews with the chief executive officers of the respective companies. The cross cases were analyzed by using analytical framework as explained 
in section 2. The unit analysis of the study is a network in the food and beverage sector, where the concept of network based on the sectoral system of innovation (SSI) is important.The substantive contribution of this scientific study is the provision of the concept of policy role in the innovation network, viewed from an SSI perspective (See, footnote 1)

\section{ANALYTICAL FRAMEWORK OFPOLICY ROLE IN INNOVATION NETWORK}

\subsection{Innovation Network}

Knowledge becomes the most important source of competitive advantage. Firms access knowledge through their network relations. A good quality of network relations and evolution determine the ease of assessing knowledge and technology (Buchmann, 2015). First, innovation networks assessing knowledge through network relations for innovation depends on 1) absorptive capacity, the more accumulated knowledge the firm has, the easier the knowledge access of the firm is; 2) technological distance, the easier external knowledge can be captured, a firm can learn more easily; 3) geographical distance, knowledge flows are typically stronger between firms in close and similar regions; and 4) experience with cooperation, a firm that is experienced in cooperation, find it more easy to obtain additional partners for cooperation (Buchmann, 2015).

Second, network evolution along the internationalization of production networks have five phases 1) initiating the networks through export and foreign sourcing; 2) developing the networks through investment in marketing and distribution facilities; 3) expanding foreign networks through investment in intermediate production of goods and services; 4) deepening and widening the network, where investments focus on developing the capabilities of affiliated firms that include investment for building human competence, physical capital, and infrastructure as well as development of business institutions; and 5) integrated network, where investment should emphasize strategic asset seeking to support a cross-border specialization strategy (Dunning \& Lundan, 2008; Aminullah et al., 2013).

\subsection{Policy Role in Innovation Network}

Innovation network viewed from SSI in this study is conceptualized as follows 1) network structure are interactions among actors in a network, 2) network tools that facilitate knowledge flow along the network and provide technology enhancement through the network, 3) network requirements are institutions in the forms of formal standards and policies that comprise of rules, procedures, and formats that define communication among actors in a network, 4) network evolution reflects a change in demand that brings a change in a network structure through internationalization as well as a change in network functions or relations, which is determined by ease of capturing external knowledge.

The network structure can be in the forms of the following interactions (Table 1): user-producer-supplier; producer-competitors, producer-knowledge centers; business cooperation, innovation collaborations; and global production integration. Network tools facilitate the flow of information (knowledge) through processes, including learning by doing, using, and interacting, and active and passive learning in the process of exploring and exploiting the sources of knowledge, whether it comes from internal or external sources. Network tools also facilitate the flows of goods (technology) over the network where ICT plays an important role in technology transfer, exploration, and exploitation. Network requirement rules which influence the relationship among actors over the network can be through mandatory, voluntary, or private standards. Network evolution is a change in scale and scope of network that is represented by moving toward global production network supported by market and non-market relations.

The effect of an innovation network on a production network viewed from a policy perspective is termed as "policy role in an innovation network." The policy role in an innovation network can be described as follows: 1) intensifying the interactions among actors of an innovation network by promoting industrial cluster, providing intermediaries, and collaborative research fund; 2) facilitating the flow of information and knowledge for accelerating the process of 
Table 1.

Analytical Framework of Policy Role in Innovation Network

\begin{tabular}{|c|c|c|c|c|}
\hline \multirow{2}{*}{ Entity } & \multirow{2}{*}{ Network Component } & \multirow{2}{*}{ SSI Element } & \multicolumn{2}{|c|}{ Policy Role in Innovation Network } \\
\hline & & & Innovation Network & Policy Role \\
\hline \multirow{5}{*}{ Netwrok } & Network Structure & $\begin{array}{l}\text { Actor and } \\
\text { network }\end{array}$ & $\begin{array}{ll}\text { - } & \text { User-producer-supplier } \\
\text { - } & \text { Producer-competitors } \\
\text { - } & \text { Producer-knowledge centers } \\
\text { - } & \text { business cooperation, innovation } \\
\text { collaboration, global production } \\
\text { integration }\end{array}$ & $\begin{array}{ll}\text { - } & \text { Clustering promotion } \\
\text { - } & \text { Provide Intermediaries } \\
\text { - } & \text { Collaborative research } \\
& \text { fund }\end{array}$ \\
\hline & Network Tools & Knowledge & $\begin{array}{ll}\text { - } & \text { Modes of learning } \\
\text { - Source of knowledge (Internal } \\
\text { and external) }\end{array}$ & $\begin{array}{l}\text { - facilitating knowledge } \\
\text { exchange }\end{array}$ \\
\hline & & Technology & $\begin{array}{ll}\text { - } & \text { Role of ICT } \\
\text { - } & \text { Technology transfer and adoption } \\
\text { - } & \text { Technology exploration and } \\
\text { exploitation }\end{array}$ & $\begin{array}{ll}\text { - } & \text { ICT Support for SME`s } \\
\text { global market } \\
\text { - } \quad \text { Researcher mobility }\end{array}$ \\
\hline & Network Requirements & Institution & $\begin{array}{l}\text { - Mandatory, voluntary, private } \\
\text { standards }\end{array}$ & $\begin{array}{l}\text { - Standard, regulation, } \\
\text { certification }\end{array}$ \\
\hline & Network Evolution & Demand & $\begin{array}{ll}\text { - } & \text { Local, national, global } \\
\text { - } & \text { Market, and non-market relations }\end{array}$ & $\begin{array}{ll}\text { - } & \text { Market access } \\
\text { - } & \text { Market promotion }\end{array}$ \\
\hline
\end{tabular}

Source: Constructed by Aminullah from Malerba and Vonortas (2009); Cunningham and Ramlogan (2012); and Buchmann (2015).

learning by facilitating knowledge exchange; 3 ) facilitating the flows of goods and technology by providing ICTs support for Small, Medium Enterprises (SMEs) in entering the global market; 4) enforcing the rules, regulations, and procedures that govern the relationship among actors over the network through standards, regulations, and certifications; and 5) stimulating firms to move from local to national and global markets as well as developing production through market and non-market relations by facilitating market access and promotion.

\section{CASE STUDIES' FINDINGS}

\subsection{Case 1: Company A}

\subsubsection{Brief history}

Company A is an Indonesian company established in 1946. The company is located in Jakarta and initially produced powder for headache in a single dose. Since 1974, the company has begun to produce ethical drug products. The company has grown to be a modern healthcare company since PT X acquired them in 1985. Two large factories were established in Jakarta, one factory produces drugs and the other produces functional food and drinks.

The company has a vision to be the most admired and respected company in healthcare in South East Asia. To achieve the vision, its missions are to provide innovative and quality products as well as affordable to common people. The company has 46 branches with 1,456 employees. The company's products meet International Organization for Standardization (ISO) 14000, Hazard Analysis Critical Control Point (HACCP), and Occupation Health and Safety Assessment System (OHSAS).

\subsubsection{Innovation and upgrading}

The company produces various functional food and drinks, including "EJ," which is one of the famous energy drink brand launched in 1994. The "EJ" idea came from the increasing of customer demand for energy drinks, particularly from middle-low income consumers who expected a product at a reasonable price. The company developed EJ based on their experience and competence in producing a single dose product in a sachet. The use of a new type packaging 
contributed in reducing the cost of packaging and transportation. The combination of product and process innovations successfully placed EJ as a market leader. The company maintains its reputation by meeting consumer's expectation, securing quality of raw materials, and obeying national and international standards, including Halal certificate.

Innovation has been the result of in-house $\mathrm{R} \& \mathrm{D}$ and collaboration across departments. The company engages in product upgrading to enter new markets, while retaining itself as a leader in the existing market. In the mid-1990s, EJ succeeded in the low-end market or the beverages of street markets. The series of product upgrading efforts were made by continuously develop new variants for a variety of consumer's needs. Since 2000, many variants of EJ have been launched. For the middle class consumers, the company conducts product promotions incooperation with sports events, mass media, and television, and has launched a new market slogan "millennial generation."

\subsubsection{Learning events and networks}

The company secured its position as a market leader in energy drinks by involving many professionals, both inside and outside the company. The professionals have taken significant roles, in terms of product upgrading, securing supply and distribution, achieving wide market, and in building strong brand and consumer relations. However, one of the advantages to limited focus on the business, the competitors became stronger. As a result, the market position of EJ decreased and was nearly over taken by competitors in the 2000s. The decreasing business of energy drinks reached a turning point in 2010, when the director began to restructure and refocus the business.

Learning from the event of racing in market competition, the company believes that ensuring best quality for the consumers is the key to success. Besides continually upgrading its products, the company engages in upgrading the marketing function. The company built partnerships to regain its market position. For example in 2007 to enter the global market, Company A developed business partnership with Company Y, an international and popular soda drink producer. Through this partnership the company ensured that products are available in the market at appropriate times; Company Y has the right to produce and distribute the product in new packages.

Since 1985, Company A established "quasihierarchy relations" with Company X, where Company A is legally independent, but the hierarchically subordinate of the principal Company $\mathrm{X}$, an international health and pharmaceutical company in Indonesia. The company has obtained support from its principal in distributing its products in the international market. The principal has established international branch offices in ASEAN countries and South Africa. In particular, in the Philippines market, the company established a joint venture with a local company "Zholdings" to market the energy drink.

The company developed "arm's length market relation" by supporting small and medium businesses, such as cooperatives, as its business partners. It governs the relationship with farmers and fishermen cooperatives that have thousands of cooperative outlets in Indonesia. It also governs the non-market relations, such as public and government networks. For example, the company supports the government's reward for athletes in international sporting competitions and product promotion through the sponsorship of national sports events.

The success in local markets has motivated the company to expand its market to other countries. To understand the characteristics of the global market, the company cooperates with a global information technology (IT) company. The IT company helps in collecting and examining market information from various countries for Company A's business decisions, which has exported EJ to the Philippines, Singapore, Malaysia, Cambodia, Hong Kong, India, Yemen, New Zealand and South Africa. In 2003, the product received the "Precious Brand" award in the Philippines. The network effect for the company's innovation is shown in Figure 1. 


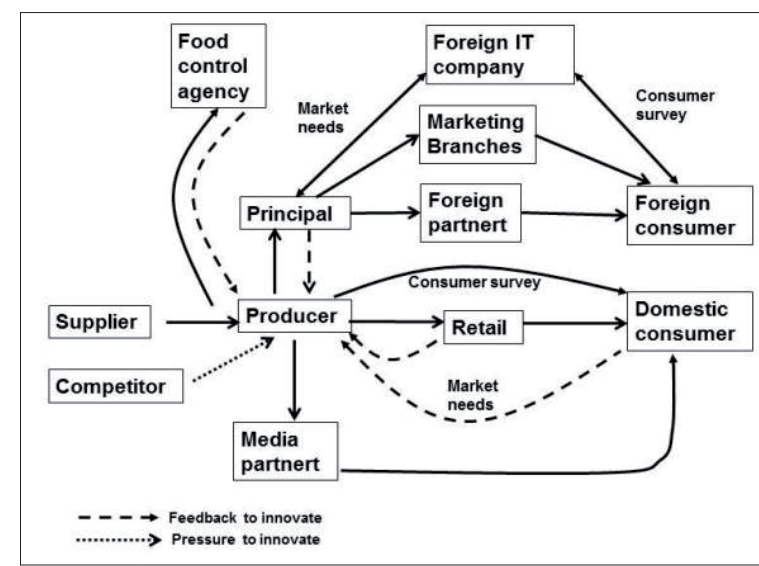

Figure 1. Innovation Network in Company A

\subsubsection{Learning mechanism}

The company has taken a long time to reach the global market. The key to its success is learning from competitors, collaboration with vendors/ wholesalers, distributors, and suppliers, understanding consumers' characteristics, and carefully studying existing regulations and standards. Since the product's first launch in 1995, the company has widely distributed its products to the Indonesian market. Its collaboration with local distributors and retailers created the company's distribution network that makes the products of the company to be easily found by consumers of various market segments.

The marketing branches overseas and full understanding of consumers' characteristics, culture, and competitors contributed EJ to enter the global market. The deep knowledge about their business and consumers was supported by IT professionals in collaboration with the marketing department, who supplied important information for the expansion of its product to the international market. Currently, EJ has approximately $80 \%$ market share in the Philippines. In ASEAN countries, its market share is approximately $20 \%$.

The company strengthened its human resource capacity by providing staffs with on the job and management training facilities at the Jakarta headquarters. Feedbacks from retailers and consumers, and market trend have been seriously taken into consideration to improve products and processes. The marketing department analyzes this information and shares the results with the
R\&D and production departments for the new products consideration. In addition, the company has applied benchmarking strategies to learn new systems, products, and processes, such as visiting new international vendors for packaging and learning new operational systems.

\subsubsection{Policy role}

In terms of standards, the Indonesian standard for functional food is closely related to medicinal standards, which are mostly higher than food standards. The government regulation on the label of functional food or energy drink promotion is heavily protecting consumers, similar to medicine promotion. Given the company's obligation to comply with these standards, the long process of standard requirements and fulfilling the strictly scientific evidence could result in a delay in the launch of products.

To enter the international market, the international division of the company's lead-firm manages the company's international network, including meeting food standards in the countries of export destination. The government role in stimulating market mechanism has contributed to the success of the company's international operation.

Government regulations on import restrictions have increased production costs and reduced the availability of raw materials. Even though the company is able to collaborate with local suppliers, the government supportive regulations for ease in doing business such as providing incentive for the business process is significantly helpful.

To accelerate innovation, the company currently collaborates with another private company to develop its products. The company is also willing to invest in research activities in collaborating with public research institutes and universities as well as in commercializing its R\&D outputs in order to expand the company's network.

\subsection{Case 2: Company B}

\subsubsection{Brief history}

Company B established in 1979 started as a small (home-scale) enterprise. The owner had an educational background in consumer psychology, 
which contributed to the development of its strong brand. At the time of establishment, the market was dominated by Japanese brands, which inspired the owner to create X brand, which refers to "many people say delicious." The company is the pioneer of producing instant food seasoning mix, coating mix, chili powder, and bread crumbs that are authentic food recipes of Indonesia. All products produced by the company met Hazard Analysis and Critical Control Point (HACCP) standards and Halal certification requirements.

In the initial phase, the company sold products through one wholesaler to serve the local market and a few were sold through distributors for export market. In 1993, the company built a modern factory in Tangerang, near Jakarta, and employed 400 workers. Since then, the company has been continuously producing diversified and new products in the new factory. Currently, the company produces all products based on Indonesian authentic recipes, which fulfils approximately $90 \%$ of the local market and $10 \%$ for export market.

\subsubsection{Innovation and upgrading}

At the beginning of 1979, the company produced products manually. In 1984, the company expanded the business by investing in new factory building. The factory line continued to be simple and manual by using very limited machineries. With the existing facilities, the company engaged in product innovation to increase added value by developing wet seasoning/processing and launched innovative products, such as coated mix (two recipes), pudding, and new variants of seasoning mix. In line with product upgrading, the company developed new products inspired by consumer's lifestyle in food consumption. The company's innovation products become a key of its survival and competitiveness.

In 1993, the company upgraded by installing new machines in its modern factory and succeeded to diversify products, such as fried banana coated mix and fried chicken coated mix with various recipes. In early 2000, based on customers preference and suggestions, the company upgraded its production function by innovating different food products. The company produced healthy instant noodles by launching "vegetable noodles". Since 2001 , the company has developed and promoted new products with new brands and new packaging design for export market. The company built a dedicated R\&D department in 2001, which is separated from the production department.

Since 2000, Internet of Things (IOTs) has been influencing the way of businesses operate in Indonesia. Online business has been utilized as the fastest way to reach the market as well as to communicate with buyers and suppliers, and to support the company's internal communication. The other drivers of the company's product upgrading are standards and regulations. Examining the standards and regulations of the export destination country is the first step to enter a new market.

\subsubsection{Learning events and networks}

The founder had successfully brought the company's growth from a home-scale enterprise to the world class manufacturing company. The company's products attracted foreign consumers, particularly to meet the demand of the Indonesian diaspora in the Netherlands, and other countries, such as Australia, the United States of America (the United States), Hong Kong, and other European Union countries.

The company experienced down turn in 2001 after the founders passed away. After facing challenging times, the company's executives began to modernize the business line in terms of management, infrastructure, production facilities, distribution, $\mathrm{R} \& \mathrm{D}$, and administration system. Restructuring the internal organization contributed to the company securing its pioneer position in the coating mix product's market. Under the new management team, the company's famous brand $\mathrm{X}$ has successfully regained its market position.

Since 2007, the company has expanded its business to provide customized products for other players within the food industry. The company currently focuses on industrial and corporate customers, including major multi-national players in food and retail industries. The corporate clients are growing and have led to an increase in the company's launched product annually. 
Due to dynamic consumer's preferences, to serve the corporate market, the firm has established a specific department called "Food Services."

The company's network to serve the export market is coordinated by the export manager, who deals with importers to reach the export market. Two types of supermarkets in the international market-Asian shops and mainstream supermarkets - have sold the unique Indonesian food seasoning products. The network effect for the company's innovation is shown in Figure 2.

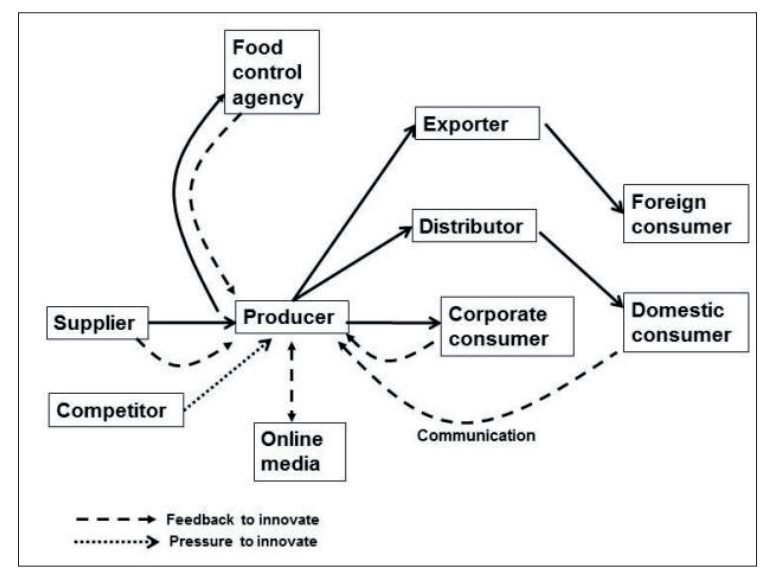

Figure 2. Innovation Network in Company B

\subsubsection{Learning mechanism}

While responding to the dynamic business environment, the company changed the ways of managing market and business systems. In terms of distributors, since 2005, the company shifted from dependence on a single distributor to relationships with multi-distributors. Considering this marketing system, the company is more effective in terms of reaching out end customers.

The company also expanded its business through market cooperation with local parties, including traditional stalls and supermarkets. All products are being sold through multi-distributors outside Jakarta area and through its own distributors for Jakarta area. For raw material supply, the company works directly with the suppliers who are able to meet the standard of raw materials for food products.

The management also focuses on expanding business to the export market. Each country has special needs and the company's products aimed to fulfill the countries' needs. The new products basically promote the menu of Indonesian taste, such as wet processing, including ketchup and seasoning, and noodles. Those products launched with a new brand for the export market. In 2007, the company also entered a new business, repackaging services, which is managed by the contract in manufacturing department. This department has repacked crackers, tea, oatmeal, and chili sauce for export oriented market.

The manner in which the company enters a new market, particularly the export market, generally begins with studying the "requirement of the food standards" of the target country. Furthermore, the export manager reviews the foreign regulation on ingredients and nutrient facts, and provides this information to the R\&D department. The R\&D department develops a new product sample by incorporating the inputs from the purchasing department. The R\&D department then designs the formula and materials that meet the food safety standard as well as gains a clearance from the internal Halal food audit (Halal guarantee system for Muslims). The sample must also pass the assessment of the internal evaluation team before mass production and distribution for the export market.

\subsubsection{Policy role}

In promoting and strengthening the innovation network, the government could bridge the access to foreign customer, including support for attending exhibition, training, and market development. The company attended international exhibitions as a means of launching and expanding its business network, including the program supported by the National Export Development Agency. An innovation network could be promoted through various training activities that focus on standard, production quality, market, and many others.

The government can promote local products for domestic and international market by 1) regulating the modern market such as supermarket and hyper mart and ensuring that there are several opportunities for local products to serve the local market. Through this policy, the local market could play a major role in the domestic market; 2) In promoting culinary tourism, government 
institutions should promote food shops in the tourism area of other countries as well as to promote its champions in culinary products. Food companies face various challenges in promoting business networks abroad, As such, it requires inter-governmental coordination. Business in food is also related to some government institutions jurisdictions, such as tourism, trade, and creative economy.

\subsection{Case 3: Company C}

\subsubsection{Brief history}

Company C was established in 1979 in Semarang, Central Java. The company started as a home-scale business and grew to become a medium-sized food and beverage industry. The idea of the business, which was initially of the owner, was to provide sugar-free nutritious food to his family who suffered from diabetes. Since its establishment, Company $\mathrm{C}$ has been committing to share and contribute on how people could live joy fully by consuming nutritious foods. This has become the company's mission "Inspiring a nutritious life". The company has three factories and has approximately 1,000 employees. Up to now, the company has marketed its products to more than 30 countries, with the main export destinations are Nigeria, Vietnam, SriLanka, Bangladesh, Yemen, Fiji, and Afghanistan.

The company has produced several brands of healthy and high taste products. The company's brand name for sweetener and high quality health foods and beverages are recognized in the national and international markets. The company applied a quality assurance system to obtain high quality products and gained international recognition, such as ISO 9001, 9002, 1702, and 21000. These recognitions have led to the company's product and process traceability. Halal certifications for all products have been obtained during the year of the product's launch. The company met all regulations of food standards and safety set by the National Agency of Food and Drug Control.

\subsubsection{Innovation and upgrading}

The company's innovation activities are organized by the research center division (RCD) and marketing division. Product innovation is led by the marketing division, while the RCD focus on product formulation research. The company engaged in food products' diversification in several categories, such as sweetener products, non-fat milk, and appendages cooking. In order to meet customer needs, the company also innovates by developing taste variants for each product category. The ideas of product innovation are mostly derived from the marketing department through consumer surveys, inputs from outlets, and research undertaken by marketing division. Ideas are formulated by marketing division and then submitted to RCD. Most of the innovation activities were conducted by RCD. Some of the research activities were conducted in cooperation with universities, such as Atmajaya, Pelita Harapan, and Bogor Agriculture Institute. All research activities are managed by researchers with educational background in food science, chemical engineering, and biotechnology.

There are three elements that drive the company to continuously upgrade and produce more innovative products. First, healthy and modern lifestyle, including increasing number of middle income class consumers, mostly the young generation, demanding more healthy food and beverage. The company is consistently responding to the market needs by upgrading and producing innovative products with better quality, more sophisticated packaging that is easy to carry, and provide a better price.

Second, professional management. The company is supported by high quality and dedicated experts in producing innovative products and services. The company acquires skills through information channels (internet) orin-house training to meet the demand of the company. The management's commitment on process upgrading was set-up through investment in machineries, workforce training, total quality programs, feedback from the user of new materials, new model, launching own brand, and entering new markets. At present, the company has applied smart manufacturing, which is directly connected with production machines for real time information.

Third, stakeholders-driven innovation. Continuous interaction with the community is ensured by educating them about healthy life- 
styles and good nutrition for a long and happy life. The interaction creates a positive feedback for continuously upgrading products and services. In spreading the practice of a healthy lifestyle, the company collaborates with the community through the establishment of the Company Inspiring Center. This center was opened for the media, community, and the company's staff for working on specific projects or to meet partners to obtain feedback on the company's products.

\subsubsection{Learning events and networks}

The changes in lifestyle toward it being modern and healthy have inspired the company to produce a variety of healthy and high taste products. From a home-scale business, the company grew into a medium-size food and beverage manufacturing company in 1979 . Since then, the company has expanded its marketing from local to national, then to global or international market. The company's marketing innovation gained several recognitions, such as the winner of "Word of Mouth Marketing" awarded by Business Media Partner in 2012 and "Top Brand" awarded by Business Media Partner in 2014.

In materializing new product development, the company pursues horizontal networks by connecting all functional units within the company, such as research, production, logistics, and marketing units, particularly in materializing new product development. Vertical networks have connected the company along a particular valueadding chain in the production process, such as local supplier as well as international vendor of raw materials and ingredients.

The company creates more value added products along the networks structure involving five activities, namely 1) new product development through cross functions as well as cooperation with another company in a "Makloon" scheme, 2) marketing and sales, 3 ) operation and logistics, 4) distribution through regional key account by retail store and national key account, including retail shops, 5) services including services using ICTs covering after and before sales services operated through customer relationship management (CRM) and customer relationship analysis. The network effect for the company's innovation is shown in Figure 3.

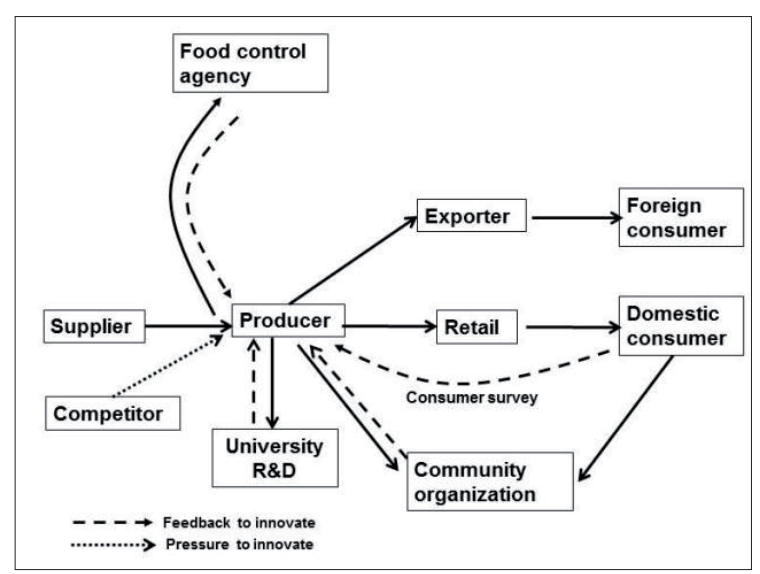

Figure 3. Innovation Network in Company C

\subsubsection{Learning mechanism}

Knowledge and skill improvement is mostly undertaken through in-house training. Innovation is also triggered by the learning process in the production and marketing units. The learning process is mostly a chain-linked process within the company and is influenced by many factors, including social factors, such as the company or work culture, passion of the employees, and support from managers. The company applies an integrated supply chain management for its business processes.

The flow of material and information is integrated by the ICT system covering supply chain management, distribution module, and finance module. The company has built network expansion in all functions, including logistics, production, and distribution. Some of the products, particularly for the Greater Jakarta area, are produced by the Makloon scheme, where all materials are provided by the company and the other partner companies undertake some production based on the company's procedures. The company manages product distribution and sales for national as well as international markets through several distributors. The company's sole distributor function is being a representative of the company's products overseas.

The uses of ICTs in all organizational functions have lowered the transaction costs in the market and increased organizational efficiency. The company provides all media, including internet access, for all employee activities. To 
support innovation activities, the company, under the Directorate of Human Resources and System, provides database related to products, processes, and marketing activities. The CRM uses IT programs to efficiently handle marketing and promotions as well as customer complains. The company also uses its web site for its marketing activities, including online selling and buying activities. Several ICT programs have been implemented to operate the company's internal interactions and external relations, such as media for user complaints, employee sharing, and virtual communication.

\subsubsection{Policy role}

The government could support the company's networking with partners through information, brokerage, and matching services, which can be arranged with trade fairs, business seminars, or providing modern information technologies. Demand of products from Asian and African countries is rather high, the government could provide trading information, including information related to export and import of food products among Asian and African countries that would provide good opportunities for companies to invest in these countries.

Supply of raw materials are other policy related issues faced by the company. The company imports raw materials and other ingredients. They are mostly imported from the United States and Australia. Instability in exchange rates will directly affect the production cost. The government should promote the domestic production of raw materials, which can be upgraded from the existing food grade of raw materials.

\subsection{Case 4: Company D}

\subsubsection{Brief history}

Company D was established in 1974 in Jakarta. The founder was a leading entrepreneur in Indonesia, who started the business as a small trader by selling un-processed meat. The business moved further to produce processed meat products (i.e., sausages) in a home-scale company. In line with the company's business growth, in 1975, a factory of the company moved to the industrial estate in East Jakarta. Since then, the factory has been producing frozen foods, particularly for the domestic market.

The company produces ready-to-eat meat processed products, such as sausages, meatballs, burgers, and kebabs. The company has 228 employees, mostly working in the factory and 34 staff in administration and marketing. The $R \& D$ and quality control units were managed by 5 staff members with educational background in food technology, chemistry, and biology. The education level of the employees in the production division is high school. The company already has HACCP certification. The company's products met the standards of food safety set by the National Agency of Drug and Food Control as well as Halal certification issued by the Islamic Ulama Council.

\subsubsection{Innovation and upgrading}

The company conducts three types of innovative product, process, and marketing innovation. First, product innovation is developed by the $\mathrm{R} \& \mathrm{D}$ division based on the marketing division's input. The $\mathrm{R} \& \mathrm{D}$ division undertook some trials for product and spice formulations. Since its establishment, the company has launched 222 variants of the company's ready-to-eat meat processed products. In addition, the R\&D division also performs customized product development for hotels, restaurants, and caters to the marketing network. The top management plays the important role of the driver of product innovation to be implemented by the R\&D division.

Second, process innovation to reduce production costs has been undertaken by the company in two ways: 1) decrease in the labor cost as a result of automation of production systems with the production machinery imported from Germany, and 2) increase in production capacity of processed meat to the level of 12 tons per day, which is significantly more than the previous manual system of production of approximately 1 ton per day.

Third, marketing innovation has been driven by competition from processed meat products, both from domestic and imported competitors. In order to respond to this challenge, the company innovates by diversifying its product brand based 
on its market segmentation. The company targets the premium market products with high price, in addition to maintaining the low end market segment with low purchasing power. Besides product diversification, the company also educates consumers in terms of handling finished products. The handling of processed meat products is important to ensure the quality of finished products before they are ready to cook.

The company is engaged in organizational innovation to increase added value by developing "intra-chain upgrading". It has also expanded the chains of network besides producing processed meat products; it also developed other businesses related to the food sector as follows: 1) agribusiness sector (i.e., hydroponic plantation in Cipanas region, West Jawa) and 2) production of fruit chips with its own brand in a factory in Cibinong, West Jawa.

\subsubsection{Learning events and networks}

The company underwent management changes after modifications in the company's ownership in 2008. The management change had a positive effect that enabled the company to be more innovative than before. In a dynamic market environment, the company took advantage of the stable demand of food industry. Learning from such situations, the company has succeeded to manage stable food supply and user driven product diversification. Hence, the company maintains its position as a specialized producer of processed meat products in Indonesia.

The company tightly manages its supply chain that ensures the quantity and quality of raw materials, production process, and product packaging. The company implemented a Halal guarantee system, where the suppliers must fulfill the Halal requirements set by the company. In managing its supply chain, the company cooperates with the National Meat Processor Association for the procurement of imported raw materials, such as beef, of high quality and sufficient quantity. In addition, the company has utilized ICTs to manage its supply chain, such as the development of supplier databases that enable firm to manage a significant number of suppliers.
The company engages in user driven product diversification where the idea of new product is influenced by consumers' needs either directly or indirectly. The company develops products based on market surveys that capture the specific needs and tastes of consumers. The information is used as a reference by the $R \& D$ unit in developing new products, both for regular and customized products. In producing new products, various regulatory testing is required. Company-owned laboratory facilities are currently inadequate to perform all such testing. The company conducted these laboratory tests by using external laboratories. The network effect of thecompany's innovation is shown in Figure 4.

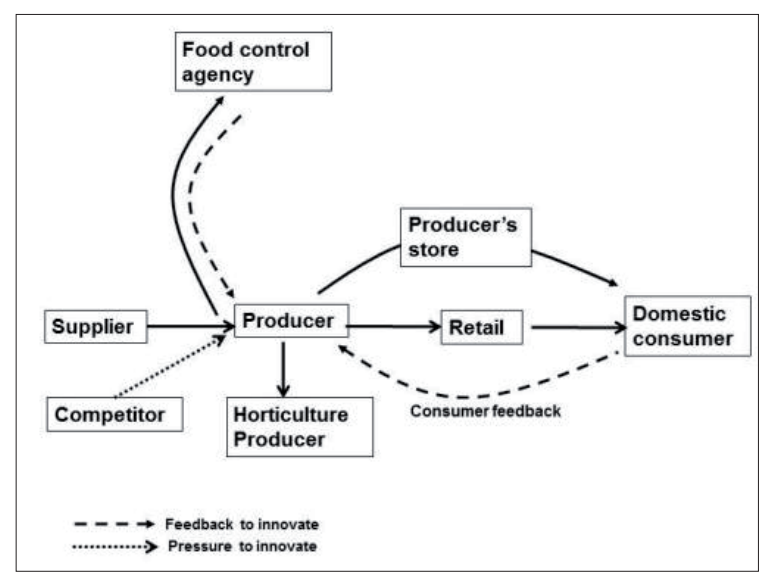

Figure 4. Innovation Network in Company D

\subsubsection{Learning mechanism}

The company enhances its innovative capability through skill improvement, reduced materials supply cost, expanded inter and intra chains of network as well as improved ways of marketing. In order to improve the knowledge and skill of the employees, the company conducts internal training regularly, where senior employees act as training mentors. The company also sends its employees for external training, such as food control training, Halal training, and hygiene training.

The company has used multiple suppliers for a particular item. In general, suppliers are divided into three categories as follows: 1) suppliers of raw materials, such as fresh meat of chicken and beef. Chicken meat suppliers come from breeders in areas surrounding Jakarta, West Java, and 
Central Java. Raw materials of beef and sausage are imported from Australia and New Zealand suppliers. 2) Suppliers of spices, both domestic and imported spices. 3) Domestic suppliers of product packaging. The company has taken measures to reduce the dependency on imported spices by replacing them with local spices in an effort to reduce production costs.

The company has two lines of marketing to reach its consumers: 1) marketing through retail and supermarket networks for various brands of products that are produced regularly. Marketing through the retail network is as much as $60 \%$ of the total product sales. 2) Marketing through hotels, restaurants, and catering networks (Horeka networks) for customized products that are produced based on the contract order. The products for hotels, restaurants, and catering are non-branded products with particular specifications. The company built its retail network by establishing a supermarket, particularly for selling fresh and frozen food. The company managed its distribution network through its marketing branch offices, while product distribution in the Jakarta area is undertaken by direct delivery of products from the factory to retail stores, hotels, restaurants, and catering networks.

\subsubsection{Policy role}

A part from government facilities, the company also needs government support related to the following: First, a stable supply of raw materials and seasonings that are mainly imported and influenced by government regulation on import restriction, while local supply is limited and does not meet the food standard requirements. Second, the involvement of the company represented by the National Meat Processor Association as the stakeholders of food regulation issued by the government.

\section{POLICY ROLE IN INNOVATION NETWORK}

\subsection{Learning events and upgrading}

Learning events or moments of significant change occurred in the four cases of food companies. Learning events vary among the companies' business lines: 1) in the energy drink company, the company regained its competitive position after the management refocused its core business in $2010 ; 2$ ) in the food seasoning company, the company modernized the business line by restructuring the internal organization and managing all functions professionally in 2001; 3) in the healthy food company, the company managed continuous learning from the beginning by applying responsive and flexible organization since 1979; and 4 ) in the processed food company, the company made management changes to make the company more competitive in the market.

The above learning events are generally related to organizational changes, such as refocusing the core business, restructuring the internal organization, undertaking management change, and applying responsive management practices. Organizational changes were undertaken by companies as a response to a decrease in company performance, which was caused by surpassing of competitors, organizational unfit in the competitive business environment, and rapid change in the business environment. Organizational changes led companies to be more competitive, regain their competitive position, and ensure continuous growth (see Table 2).

Learning events affect the companies' performance. After making significant organizational changes, company performances have increased through upgrading. Among the four cases of food companies that engaged in products, processes, and functional upgrading, only one company engaged in intra-chain upgrading. The company that undertook intra-chain upgrading is the processed meat producer. It expanded the chains of network besides producing processed meat products by shifting to other businesses related to the food sector, namely hydroponic plantation and production of fruit chips.

Three observations were made in regard to the four companies. Firstly, in terms of product upgrading, the four companies developed variants of the existing product in accordance to the change in consumer taste. Three companies engaged in new product development for different objectives, such as 1) to gain higher value by diversifying the products of food seasoning in the market, 2) to meet the demands of premium 
Table 2.

Learning Events and Upgrading

\begin{tabular}{|c|c|c|c|c|c|}
\hline \multirow{2}{*}{ Company } & \multirow{2}{*}{ Learning Events } & \multicolumn{4}{|c|}{ Types of Upgrading } \\
\hline & & Product & Process & Functional & Intra-Chain \\
\hline $\begin{array}{l}\text { Company A } \\
\text { (Energy drink) }\end{array}$ & $\begin{array}{l}\text { Since } 2010 \text {, refocus- } \\
\text { ing core business }\end{array}$ & $\begin{array}{l}\text { Develop new } \\
\text { variants }\end{array}$ & $\begin{array}{l}\text { Install new machin- } \\
\text { eries and apply new } \\
\text { packagung }\end{array}$ & $\begin{array}{l}\text { Build } \\
\text { global marketing } \\
\text { partnership }\end{array}$ & \\
\hline $\begin{array}{l}\text { Company B } \\
\text { (Food seasoning) }\end{array}$ & $\begin{array}{l}\text { 2001, restructuring } \\
\text { internal organization }\end{array}$ & $\begin{array}{l}\text { Develop new } \\
\text { products and } \\
\text { variants }\end{array}$ & $\begin{array}{l}\text { Install new } \\
\text { machineries }\end{array}$ & $\begin{array}{l}\text { Develop } \\
\text { functions of } \\
\text { production } \\
\text { network }\end{array}$ & \\
\hline $\begin{array}{l}\text { Company C } \\
\text { (Healthy food) }\end{array}$ & $\begin{array}{l}\text { Since } 1979, \text { respon- } \\
\text { sive and flexible } \\
\text { organization }\end{array}$ & $\begin{array}{l}\text { Develop new } \\
\text { product }\end{array}$ & $\begin{array}{l}\text { The use of ICT in all } \\
\text { functions }\end{array}$ & $\begin{array}{l}\text { Apply creative } \\
\text { marketing } \\
\text { techniques }\end{array}$ & \\
\hline $\begin{array}{l}\text { Company D } \\
\text { (Processed } \\
\text { meat) }\end{array}$ & $\begin{array}{l}\text { in } 2008, \text { management } \\
\text { change }\end{array}$ & $\begin{array}{l}\text { Develop new } \\
\text { product }\end{array}$ & $\begin{array}{l}\text { Automation produc- } \\
\text { tion systems }\end{array}$ & $\begin{array}{l}\text { Build marketing } \\
\text { network }\end{array}$ & $\begin{array}{l}\text { Expand to other } \\
\text { business lines }\end{array}$ \\
\hline
\end{tabular}

Source: compiled from case study

processed food in the market, and 3) to meet the needs ofhealthy food for people with a modern lifestyle.

Secondly, observing from process upgrading, each company pursued different ways of increasing efficiency, namely: 1) the food seasoning company installed new machineries in a modern factory, 2) the healthy food company used ICT in all functions to lower transaction cost and work more efficiently, 3) the process food company automated production systems to decrease the labor cost, and 4) the energy drink company automated production systems and applied new packaging for cost reduction. The latter works to reduce labor cost as well as the cost of packaging and transportation.

Thirdly, examining from a functional upgrading perspective, all the companies upgraded their organizational functions in different ways, namely 1) the energy drink company built international marketing partnership through the initiative of the principal, 2) the food seasoning company developed the function of seasoning production toward different lines of products, such as healthy noodle, 3 ) the healthy food company applied creative marketing techniques by involving stakeholders, and 4) the processed food company built a marketing network by establishing supermarket and services business.

\subsection{Innovation Network}

Innovation network is the use of network relations for innovation. The number of actors in the network relations effect upgrading the value of a good or service. In food processing companies, the structure of the innovation network is mainly user-driven innovation. The four cases of companies show that the sources of innovative ideas come from producer-customer relations, which are connected by the elements of distributors and retails. The producer-user relations in innovation are strengthened by supportive relations, namely 1) producer-media partner relation to disseminate and gain information on companies' product position in the market. This relation exists in the energy drink and healthy food companies, 2) the producer-corporate customer relations that are found in the food seasoning company, 3) producer-principal relation that bridges the gap between the company and overseas customers, and 4) producer-professional relation that bridges the gap between the company and healthy minded community. Other types of innovation network structures are: 1) producer-competitor relation, which are found in the energy drink and food seasoning companies, 2) producer-supplier relation, which is found in the food seasoning company, 3) innovation is driven by interactions with universities-R\&D institutions, such as the 
Table 3.

Variety of Network Relations for Innovation

\begin{tabular}{|c|c|c|c|c|}
\hline \multirow{2}{*}{$\begin{array}{l}\text { Network } \\
\text { Component }\end{array}$} & \multicolumn{4}{|c|}{ Variety of Network Relations for Innovation } \\
\hline & $\begin{array}{c}\text { Company A (Energy } \\
\text { drink) }\end{array}$ & $\begin{array}{c}\text { Company B (Food } \\
\text { seasoning) }\end{array}$ & Company C (Healthy food) & $\begin{array}{c}\text { Company D } \\
\text { (Processed meat) }\end{array}$ \\
\hline $\begin{array}{l}\text { Network } \\
\text { Structure }\end{array}$ & $\begin{array}{ll}\text { - } & \text { Producer- } \\
& \text { consumer } \\
\text { - } & \text { Producer-retail } \\
\text { - } & \text { Producer- } \\
\text { competitor } \\
\text { - } & \begin{array}{l}\text { Producer-media } \\
\text { partner }\end{array} \\
\text { - } & \text { Producer-foreign } \\
& \text { partner }\end{array}$ & $\begin{array}{ll}\text { - } & \text { Producer-consumer } \\
\text { - } & \text { Producer-corporate } \\
\text { customer } \\
\text { - } & \text { Producer-competitor } \\
\text { - } & \text { Producer-supplier }\end{array}$ & $\begin{array}{ll}\text { - } & \text { Producer-individual } \\
\text { - } & \text { Pustomer } \\
\text { - } & \text { Producer-retail } \\
\text { - } & \text { Producer-community } \\
\text { - } & \text { partner } \\
\text { Producer-profesional } \\
\text { - } \\
\text { Partner } \\
\text { R\&D }\end{array}$ & $\begin{array}{ll}\text { - } & \text { Producer- } \\
\text { - } & \text { consumer } \\
\text { - } & \text { Producer-retail } \\
& \text { Producer- } \\
& \text { supplier }\end{array}$ \\
\hline $\begin{array}{l}\text { Network } \\
\text { Tools }\end{array}$ & $\begin{array}{ll}\text { - } & \text { Sponsorship of } \\
\text { - } & \text { principal initiative } \\
\text { - } & \text { consumer`s } \\
\text { survey } \\
\text { - } \\
\text { partnership with } \\
\text { IT company }\end{array}$ & $\begin{array}{l}\text { - } \begin{array}{l}\text { Communication with } \\
\text { buyer and supplier }\end{array} \\
\text { - } \quad \text { on-line (internet) } \\
\text { communication } \\
\text { - repacking of products }\end{array}$ & $\begin{array}{l}\text { - } \quad \text { Consumer`s survey } \\
\text { - } \quad \text { Events of recognitions } \\
\text { ship management } \\
\text { (CRM) unit }\end{array}$ & $\begin{array}{l}\text { Bridging } \\
\text { producer and } \\
\text { consumer } \\
\text { through direct } \\
\text { retail }\end{array}$ \\
\hline $\begin{array}{l}\text { Network } \\
\text { Requirements }\end{array}$ & $\begin{array}{ll}\text { - } & \text { HACCP and halal } \\
\text { certificate } \\
\text { - } \\
\text { International } \\
\text { standards ISO }\end{array}$ & $\begin{array}{l}\text { - } \quad \text { HACCP and halal } \\
\text { certificate }\end{array}$ & $\begin{array}{ll}\text { - } & \text { HACCP and halal } \\
\text { certificate } \\
\text { - } \\
\text { International } \\
\text { standards ISO }\end{array}$ & $\begin{array}{l}\text { - } \quad \text { HACCP and } \\
\text { halal certificate }\end{array}$ \\
\hline $\begin{array}{l}\text { Network } \\
\text { Evolution }\end{array}$ & $\begin{array}{l}\text { - Initiating global } \\
\text { network through } \\
\text { export } \\
\text { Deloping global } \\
\text { network throuh } \\
\text { local partner }\end{array}$ & $\begin{array}{l}\text { - Initiating global } \\
\text { network through } \\
\text { export }\end{array}$ & $\begin{array}{l}\text { - Initiating global } \\
\text { network through } \\
\text { export }\end{array}$ & $\begin{array}{l}\text { - locally retail } \\
\text { network }\end{array}$ \\
\hline
\end{tabular}

Source: compiled from case study

one built by the health food company (see Table $3)$.

The network tools facilitate both the flows of knowledge and goods in food companies. The flow of knowledge through the process of learning is supported by ICT and the flow of goods is supported through the mechanisms of production network. The details are as follows: 1) in the energy drink company, the flow of knowledge for interactive learning is facilitated by the sponsorship of sport events, principal initiative to bridge the company relation with foreign partners, and the survey of consumer behavior on energy drink products. The flow of product along the local and global production networks are supported by the partnership with the IT companies. 2) In the food seasoning company, the flow of information is ensured through communication to gain feedback from buyers and suppliers. The company applies online communication (internet) to search for new knowledge for product development, while the flow of goods is through mechanisms of repacking the product for the export market. 3) In the health food company, the flow of information is expedited by consumer's survey on market needs and events of recognitions for information dissemination on healthy products, while the flow of goods to reach the customer is managed by using the software of CRM. 4) In the processed food company, the flow of information occurs 
by bridging the gap between the producer and consumer through the establishment of a direct retail supermarket.

Viewed from network requirement rules, the relationship among the actors over the network can be mandatory, voluntary, or private standards. All the companies met the requirements: 1) mandatory standards are set by the National Agency of Drug and Food Control, including HACCP as technical requirements for food safety, Halal certification for free of forbidden content, and labeling requirements for brands, contents, and indications. 2) Two companies that applied voluntary standards are verified through thirdparty auditing, such as standards set by the ISO. The energy drink company met ISO 14000 and OHSAS, while the health food company met ISO 9000, 17000, and 21000.

Network evolution is a change in the scale and scope of network that is represented by moving toward a global production network supported by the market and non-market relations: 1) Three companies, energy drink, food seasoning, and health food producers, moved to the global market by initiating the networks through export. Energy drink export is undertaken by the company's principal, food seasoning export is enabled by third parties as exporters, and healthy food export is organized by the company's distributor. 2) One company, energy drink producer, developed networks through investment in marketing and distribution facilities overseas in cooperation with foreign partners, while the processed meat producer still operates in the local market through local retail networks.

\subsection{Policy Role in Innovation Network}

Generally, food companies operate based on market mechanisms. Nevertheless, companies still regard the importance of policy role in innovation network and GVCs. In terms of network structure, food companies need the effective use of network relations for innovation through 1) government facilities for ease in doing business by continuing to reduce bureaucratic processes in regulating standard requirements, 2) strengthening government agencies-industry relations by establishing the promotion of representatives of Indonesian food products overseas, 3) government brokerage and matching services for global trading by arranging trade fairs, business seminars, and supporting modern information technologies, and 4) government relaxation on

Table 4.

Policy Role in Innovation Network

\begin{tabular}{|c|c|c|c|c|}
\hline \multirow{3}{*}{\begin{tabular}{l}
\multicolumn{1}{c}{$\begin{array}{c}\text { Network } \\
\text { Component }\end{array}$} \\
Network \\
Structure
\end{tabular}} & \multicolumn{4}{|c|}{ Policy Role in Innovation Network } \\
\hline & $\begin{array}{c}\text { Company A (Energy } \\
\text { drink) }\end{array}$ & $\begin{array}{l}\text { Company B (Food } \\
\text { seasoning) }\end{array}$ & Company C (Healthy food) & $\begin{array}{c}\text { Company D } \\
\text { (Processed meat) }\end{array}$ \\
\hline & $\begin{array}{l}\text { gov facilities for } \\
\text { easiness in doing } \\
\text { business }\end{array}$ & $\begin{array}{l}\text { - gov agencies-industry } \\
\text { relations }\end{array}$ & $\begin{array}{l}\text { - gov brokerage and } \\
\text { matching services }\end{array}$ & $\begin{array}{l}\text { - gov relaxation } \\
\text { on import } \\
\text { restriction }\end{array}$ \\
\hline $\begin{array}{l}\text { Network } \\
\text { Tools }\end{array}$ & $\begin{array}{l}\text { - } \quad \text { stimulating mar- } \\
\text { ket mechanism }\end{array}$ & $\begin{array}{l}\text { - government support } \\
\text { in export promotion }\end{array}$ & $\begin{array}{l}\text { - gov brokerage and } \\
\text { matching services }\end{array}$ & $\begin{array}{l}\text { - } \text { government- } \\
\text { business } \\
\text { association } \\
\text { cooperation }\end{array}$ \\
\hline $\begin{array}{l}\text { Network } \\
\text { Requirements }\end{array}$ & $\begin{array}{l}\text { foreign country`s } \\
\text { food standard }\end{array}$ & $\begin{array}{l}\text { - export country`s food } \\
\text { standard }\end{array}$ & $\begin{array}{l}\text { foreign country`s food } \\
\text { standard, FSMA, EFSA }\end{array}$ & $\begin{array}{l}\text { - } \quad \text { HACCP and } \\
\text { halal certificate }\end{array}$ \\
\hline $\begin{array}{l}\text { Network } \\
\text { Evolution }\end{array}$ & $\begin{array}{l}\text { Incentives } \\
\text { for investing } \\
\text { global production } \\
\text { network }\end{array}$ & $\begin{array}{l}\text { Incentives for export } \\
\text { market penetration }\end{array}$ & $\begin{array}{l}\text { - Incentives for } \\
\text { exploring more export } \\
\text { market opportunity }\end{array}$ & $\begin{array}{l}\text { - Support for } \\
\text { stable supply } \\
\text { of imported } \\
\text { material }\end{array}$ \\
\hline
\end{tabular}

Source: compiled from case study 
import restriction to maintain a stable supply of raw materials for food processing (see Table 4).

Viewed from network tools, the policies needed to facilitate the flow of knowledge and technology for accelerating the process of learning as well as for facilitating the flows of goods entering the global market are as follows: 1) government incentives, in terms of financial and fiscal incentives, to reduce the cost of production will help market mechanisms to function properly, 2) government support in export promotion by intensifying the role of export promotion agency, 3) government brokerage and matching services by arranging trade fairs, and 4) government and business cooperation supporting the role of association in ease import restriction.

The policy role is significant for regulating network requirements, particularly mandatory standards, which are set by the Indonesian Food and Drug Authority (BPOM), including HACCP as technical requirements for food safety, Halal certification for free of forbidden content, and labeling requirements for brands, contents, and indications. The standards of food safety are internationally enforced by many countries. Food companies must meet the standard set by foreign countries of export destination. It includes the foreign country's food standard, such as Food Safety Modernization Act in the United States and European Food Safety Authority.

The policy role in network evolution by stimulating companies to move from local to national and global markets is related to facilitating market access and market promotion overseas. The government needs to provide incentives (financial and fiscal) for exploring more export market opportunities, initiating export market penetration, and developing investment in global production networks.

\section{CONCLUSION AND POLICY IMPLICATIONS}

The number of actors in network relations affects the upgrade of value of a good or service. The upgrading is activated by learning events, which are related to organizational changes, namely refocusing the core business, restructuring the internal organization, undertaking management change, and applying responsive management practices. Organizational changes were undertaken by companies as a response to decreases in company performances. Subsequent to making significant organizational changes, the companies' performances increased mainly through upgrading of products, processes, functional upgrading, and less engaged in intra-chain upgrading.

The characteristics of using network relations for innovation in food processing are: 1) the structure of innovation network is mainly user-driven innovation, where the sources of innovative ideas come from producer-customer relations, who are connected by the elements of distributors and retailers; 2) the network tools facilitate the flows of both knowledge and goods in food processing. The flow of knowledge through the process of learning is supported by ICT facilities and the flow of goods is supported through the mechanisms of production network; 3 ) network requirements rule the relationship among actors over the network in food processing and it met the requirements of mandatory standards, including HACCP, Halal certificate, and labeling requirements; 4) network evolution is moving toward global production network supported by market and non-market relations. Generally, food processing companies' move to the global market by initiating network evolution through export mechanisms, where in expanding to the overseas market network, the role of the lead firm is important.

The general policy role in stimulating networks that affect innovation in food processing companies are government support: 1) for the effective use of network relations for innovation, 2) to facilitate the flow of knowledge and technology for accelerating the process of learning as well as to facilitate the flows of goods entering the global market, 3 ) to provide excellent service in enforcing mandatory standards for food processing, 4) to facilitate market access and market promotion overseas for companies to move from local to national and global markets. 


\section{ACKNOWLEDGMENT}

We are grateful to ERIA for providing the research grant under ERIA-IDE/JETR0 research project 2016/2017. We are indebted to Prof. Patarapong Intarakumnerd, Dr. Machikita Tomohiro and Dr. Yasushi Ueki for their contribution for the substantial improvement of this paper and making this paper eligible for publication.

\section{REFERENCES}

Aminullah, E., Fizzanty, T., Sari, K., Rahmaida, R., \& Susanto, Q. M. B. (2017). Interactive learning for upgrading and growth: Case of Indonesian fishery firms. Journal of STI Policy and Management, 2(1), 29-42. doi: http://dx.doi. org/10.14203/STIPM.2017.115

Aminullah, E., Fizzanty, T., Kusnandar, K., \& Wijayanti, R. (2013). Technology transfer through OFDI: The case of Indonesian natural resource based MNEs. Asian Journal of Technology Innovation, 21(S1): 117. https://doi.org/10.10 80/19761597.2013.819236

Buchmann, T. (2015). The evolution of innovation network: an automotive case study. Wiesbaden: Springer Gabler.

Cunningham, P., \& Ramlogan, R. (2012). The effects of innovation network policies. National Endowment for Science, Technology and the Arts (NESTA) Working Paper, No. 12/04, March.

Dunning, J. H., \& Lundan, S. M. (2008). Multinational enterprises and the global economy ( $\left.2^{\text {nd }} \mathrm{ed}\right)$. Cheltenham: Edward Elgar.

Ehrich, M., \& Mangelsdorf, A. (2018). The role of private standards for manufactured food exports from developing countries. World Development, 101, 16-27. DOI: 10.1016/j. worlddev.2017.08.004

Enzing, C. (2009). Product innovation in the Dutch food and beverage industry: A study on the impact of the innovation process, strategy and network on the product's short-and long-term market performance. Wageningen: Wageningen Academic Publishers.

Handayani, M. \& Permawati, H. (2017). Gamma irradiation technology to preservation of foodstuffs as an effort to maintain quality and acquaint the significant role of nuclear on food production to Indonesia society: A review. Energy Procedia, 127: 302-309. https://doi.org/10.1016/j. egypro.2017.08.112
Humphrey, J., \& Schmitz, H. (2002). How does insertion in global value chains affect up-grading in industrial clusters? Brighton: Institute of Development Studies.

Khan, I., Tango, C. N., Miskeen, S., Lee, B. H., \& Deog-Hwan. (2017). Hurdle technology: A novel approach for enhanced food quality and safety-A review. Food Control, 73, 1426 -1444 .

Martinez-Gomez, V., Domenech, J., \& Mas-Verdú, F. (2016). Adoption of ICT innovations in the Agri-food sector: An analysis of French and Spanish industry. In Charis Galanakis (ed.), Innovation Strategies in the Food Industry: Tools for Implementation (pp. 237-249). Cambridge: Academic Press.

Malerba, F. (ed.). (2004). Sectoral System Innovation: Concepts, Issues and Analysis of Six Major Sectors Europe. Cambridge: Cambridge University Press.

Malerba, F., \& Sunil, M. (Eds.). (2009). Sectoral system innovation and production in developing countries: Actors, structure and evolution. Cheltenham: Edward Elgar.

Malerba, F., \& Vonortas, N. S. (2009). Innovation Networks in Industries. Cheltenham: Edward Elgard.

Rahmat, S., Cheong, C. B., \& Rizal Bin Abd Hamid, M. S. (2016). Challenges of developing countries in complying quality and enhancing standards in food industries. Procedia-Social and Behavioral Sciences, 224, 445-451.

Schiefer, G., \& Deiters, J. (2016). Food innovation dynamics and network support. In Charis Galanakis (Ed), Innovation strategies in the food industry: Tools for implementation (pp. 1-17). Cambridge: Academic Press.

Vallauri, U. (2014). Transition Belsize Veg Bag scheme: The role of ICTs in enabling new voices and community alliances around local food production and consumption. Futures, 62, 173-180. https://doi.org/10.1016/j. futures.2014.04.008 